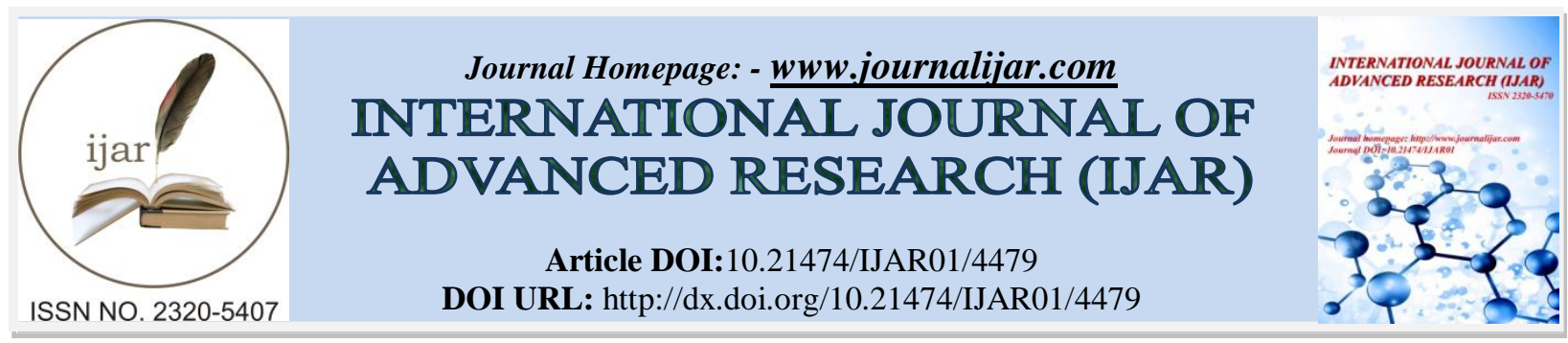

RESEARCH ARTICLE

\title{
RELATIONSHIP BETWEEN CAPITAL STRUCTURE AND EARNINGS PER SHARE - A STUDY ON THE SELECTED INDIAN AUTOMOBILE COMPANIES
}

Dr. Pradip Kumar Das.

1. Associate Professor and Teacher-in-Charge, Commerce Unit, Jagannath Kishore College, Purulia (W.B.), India

2. Affiliation under S.K.B. University, Purulia

\section{Manuscript Info}

-........................

Manuscript History

Received: 13 April 2017

Final Accepted: 15 May 2017

Published: June 2017

Key words:-

Optimal Capital Structure, Debt-Equity

Ratio, Dynamic Environment, Earnings per Share, Judicious Use.

\section{Abstract}

The pattern of capital structure is of vital importance in financial decision making for the well being of any company. Optimal capital structure decisions influence the risk and return of the investors. Hence, capital structure not only minimizes the cost of capital for the company but also maximizes the market price of the shares. In a dynamic environment, a company has to take a lot of precautions while designing its capital structure and raising additional funds. The judicious use of debt and equity for appropriate capital structure is one of the major requisitions of the company. The present study is a modest attempt to compare the pattern of the capital structure or debtequity ratio and its influence on earnings per share on automobile industry by choosing six popular and established companies for a specific period of time. The study observes in most of the cases dependence of earnings per share (EPS) on debt-equity in automobile industry in India. In few cases, they are not highly dependent due to some other possible reasons.

\section{Introduction:-}

Capital Structure refers to the type of securities issued by a concern and their proportions that make up the total capitalization. Simply, the combination of debt and equity is known as capital structure. An optimal capital structure maximizing the market value per share or minimizing the average cost of capital helps generate sound earnings for the equity shareholders which in turn, reflect the performance of company and ultimately help to generate goodwill. In fact, optimal capital structure is a well-balanced capital structure which satisfies all the objectives of a sound capital structure and enjoys the features of flexibility, easy manageability and solvency. In practice, it is almost an invincible task to determine an optimal capital structure. Overall, an approximation of optimum level is made for taking financial decision. Khan and Jain ${ }^{1}$ very wisely stated, "What should be attempted is an appropriate capital structure, given the facts of a particular case". Capital Structure decision is one of most critical areas of financial decision due to its inter connection with other financial decision parameters. Sound capital structure decision lowers the cost of capital and maximizes the value of the investors. The composition of capital leads to a separate kind of organization policy and thus, draws attention for analyzing its effectiveness. In this situation, an effort is initiated on Indian automobile companies to shed some lights on the factors causing the choice of capital structure. Therefore, this research work undertakes study of the six reputed and matured automobile companies from automobile industry in India on the basis of availability of five years balanced panel data commencing from 2012 to 2016. The return on 
capital employed signifies the profitability of an enterprise. The expected earnings per share as a measure of capital investment is always a tool to regulate the choice of capital (debt or equity) as a trade off with the cost of acquiring it. The aim of this study is to carry out an empirical analysis, using secondary data to determine the relationship between capital structure and earnings per share of selected companies in India. The current study is organized into seven sections, including the present one. Section-2 reveals the objectives of the research study. Section-3 deals with review of literature. Section-4 has been designed to present the research database and methodology. Section-5 is concerned with a brief profile of the automobile industry in India. Section-6 deals with empirical analysis and major findings of the study. Finally, Section-7 depicts conclusion of the present study covering all the remaining chapters.

\section{Objectives of the Study:-}

Behind every research study there must have been some definite objectives which helps to construct a guiding principle to the entire study. To be specific, the study attempts to address the following objectives:-

1. To analyze the debt-equity structural impact on earning per share.

2. To establish a relationship between debt-equity ratios i.e. capital structure and earning per share of six companies belonging to automobile industry in India through various statistical tools and techniques.

\section{Review of Literature:-}

Many empirical studies have been made in India and outside India on various issues of capital structure. Singh and Luthra $(2013)^{2}$ visited the capital structure puzzle and concluded that the optimal capital structure maximizes the shareholders' return. Pratheepkanth (2011)3 examined some companies in Colombo Stock Exchange. His hypothesis stands there is a negative relation between the financial performance and capital structure of the companies. Shubita and Alsawalhah (2012)4 established that increase in debt capital structure decreases the profitability, whereas in Iran, Mohammadzadeh and others (2013)5 concluded that inside financing shows a greater positive impact on profitability. Poddar and Mittal (2014)6 examined the capital structure to find out the determinants and concluded that the size of companies does impact the leverage of the firm and they can attract the debt easily from the market at the same time the profitability it bears the impact from leverage. Modigliani and Miller (1958) ${ }^{7}$ originally proved under the assumption of no taxes and developed capital structure irrelevancy propositions in a perfect capital market. Later, this concept of Modigliani and Miller (1958) was relaxed by incorporating corporate tax into account (Modigliani and Miller, 1963) ${ }^{8}$ which recognized that the value of the firm will change with the using of debt in the capital structure on account of tax shield on interest on debt. Subsequently, Myers (1977) ${ }^{9}$ incorporates personal taxes into account and argued that like corporate taxes, personal taxes also have an impact on capital structure. Graham $(2000)^{10}$ confirmed the argument and stated that each and every firm will try to strike a balance between the expected benefits and expected costs derived from taxes. Ultimately, MM theory has been criticized from different angles through many empirical and theoretical studies e.g. Harris and Raviv, 1991 ${ }^{11}$, Myers, $2001^{12}$ and three alternative theories of capital structure such as the trade-off theory, the peeking order theory and the agency cost theory have been emerged to overcome the problems of the earlier one.

\section{Database and Methodology:-}

The researcher being an external analyst has to depend mainly upon secondary data for the examination of the fundamental aspect of capital structure and earnings per share of the selected companies i.e. Bajaj Auto Ltd., Tata Motors Ltd., Hero Moto Corp., Maruti Suzuki, Ashok Leyland and TVS Motor Company of Automobile Industry in India. Hence, the data required for the study have been collected mostly from the annual reports of the companies for the period from 2012 to 2016 and these have been further supplemented by "on the spot studies". Discussions and personal interviews were held with the officials and the company executives at the company and the head office levels and different office bearers of the companies. On the spot studies were carried out with the help of questionnaires issued to the companies. The tentative questionnaires were pre-tested with the workers, management personnel and office bearers of the companies. Though there was found apathy or indifference on the part of executives in supplying information, the researcher could overcome the same through moral persuasion and intensive pestering. It was made clear to them that the information so collected will be exclusively used for academic purpose and proper secrecy will be maintained. With a view to getting an idea of capital structure and earnings per share in reputed automobile companies, six reputed and matured automobile companies in India have been selected and studied. Different statistical measures and techniques like Mean, Spearman's Rank Correlation, OLS Regression Results with and without Time Dummies, etc. have been applied for the purpose of the study and analysis. 


\section{A Brief Profile of Indian Automobile Industry:-}

Automobile industry contributes a major part of manufacturing industry, which actually is a backbone of Indian economy. The Automotive Mission Plan (AMP), 2016-2026 of Ministry of Heavy Industries and Public Enterprises aims at contributing more than $12 \%$ of GDP (i.e. Gross Domestic Product which is at present $7.2 \%$ ) to the automotive sector and creates an additional employment of 65 million people with an output of $\$ 260-\$ 302$ billion leading the automobile industry to shine on global platform. Despite these, the industry in India has been facing many challenges in competing with the multinational companies in the world. The major challenges now before the industry are achievement of economies of scale, reduction in cost, development of international market, removing bottlenecks of infrastructure, automation of work and proper deployment of resources, etc. In addition, the industry is now concentrating on green technologies likes hybrid vehicles, low discharge of effluents and fuel-efficient engine, thrifty engineering and should elevate the export turnover.

\section{Analysis and Major Findings:-}

Table- I and Table- II show simply debt-equity ratio and earnings per share of the selected companies. Table-III shows average of debt-equity ratio and earnings per share of the companies under study. Table - III evidences that on an average, debt-equity ratio and earnings per share of Bajaj Auto Ltd. were 0.01 time and Rs. 108.90; in Tata Motors Ltd., these were 0.81 time and Rs. (-) 1.64; in Hero Moto Corp., these were 0.06 time and Rs. 121.42; in Maruti Suzuki India, these were 0.05 time and Rs. 100.42; in Ashok Layland, these were 0.84 time and Rs. 1.52 and in TVS Motor Company, these were 0.47 time and Rs. 5.92 respectively. Highest debt-equity ratio was observed in Ashok Layland and lowest in Bajaj Auto Ltd. Similarly, highest earning per share was observed in Hero Moto Corp. and lowest in Tata Motors Ltd.

From the analysis of debt-equity i.e. capital structure and earnings per share, it is observed that they were not much co-related with each other. Applying Edward Spearman's formula for rank correlation coefficient, the value of correlation coefficient was found to be -2.1 i.e. negative which signifies that capital structure and earnings per share were negatively associated or mildly related to each other. Probable error tells us the limit within which the various values of the coefficient of correlations of the various samples taken out of same group or the entire group will vary. If the coefficient of correlation is less than the probable error, the ' $r$ ' is insignificant i.e. negative correlations were very significant ${ }^{13}$. Table - IV also supports this relationship.

To study the trend in the value of earning per share of the six select automobile companies for the last five years from the annual reports and by virtue of these data how far debt-equity ratio affects earning per share of these automobile companies, OLS Regression analysis with Time Dummies (Table-V) and OLS Regression analysis without Time Dummies (Table-VI) have been adopted. Using OLS Regression analysis it is possible to predict earning per share for a given debt-equity proportion. Fitting data of the select companies in the automobile industry shows that at $1 \%$ level, the time dummies are insignificant; but debt-equity or capital structure has a significant influence on earning per share. Actually, earning per share is not only dependent on debt-equity ratio or capital structure but it depends on some other variables also.

Table I:- Debt-Equity Ratio (Time/s) for the Selected Companies under Study.

\begin{tabular}{|c|c|c|c|c|c|}
\hline Name of the Company & 2012 & 2013 & 2014 & 2015 & 2016 \\
\hline Bajaj Auto Ltd. & 0.02 & 0.01 & 0.01 & 0.01 & 0.01 \\
\hline Tata Motors Ltd. & 0.56 & 0.75 & 0.76 & 1.35 & 0.63 \\
\hline Hero Moto Corp. & 0.24 & 0.06 & 0.00 & 0.00 & 0.00 \\
\hline Maruti Suzuki India & 0.07 & 0.07 & 0.08 & 0.01 & 0.00 \\
\hline Ashok Layland & 0.83 & 1.11 & 1.19 & 0.63 & 0.44 \\
\hline TVS Motor Company & 0.61 & 0.45 & 0.34 & 0.56 & 0.39 \\
\hline
\end{tabular}

Source: - 1) Annual Reports and Accounts, 2) Spot Studies; Results Computed.

Table II:- Earning Per Share (Rs. in crore) for the Selected Companies under Study

\begin{tabular}{|c|c|c|c|c|c|}
\hline Name of the Company & 2012 & 2013 & 2014 & 2015 & 2016 \\
\hline Bajaj Auto Ltd. & 103.80 & 105.20 & 112.10 & 97.20 & 126.20 \\
\hline Tata Motors Ltd. & 3.90 & 0.93 & 1.03 & -14.72 & 0.68 \\
\hline Hero Moto Corp. & 119.09 & 106.07 & 105.61 & 119.46 & 156.86 \\
\hline Maruti Suzuki India & 56.60 & 79.19 & 92.13 & 122.85 & 151.33 \\
\hline
\end{tabular}




\begin{tabular}{|c|c|c|c|c|c|}
\hline Ashok Layland & 2.13 & 1.63 & 0.11 & 1.20 & 2.54 \\
\hline TVS Motor Company & 5.24 & 2.44 & 5.51 & 7.32 & 9.10 \\
\hline
\end{tabular}

Source: - 1) Annual Reports and Accounts, 2) Spot Studies; Results Computed.

Table III:- Average of Debt-Equity Ratio and Earning Per Share of the Selected Companies.

\begin{tabular}{|c|c|c|}
\hline Name of the Company & Debt-Equity Ratio (Time) & Earning Per Share (Rs.) \\
\hline Bajaj Auto Ltd. & 0.01 & 108.90 \\
\hline Tata Motors Ltd. & 0.81 & -1.64 \\
\hline Hero Moto Corp. & 0.06 & 121.42 \\
\hline Maruti Suzuki India & 0.05 & 100.42 \\
\hline Ashok Layland & 0.84 & 1.52 \\
\hline TVS Motor Company & 0.47 & 5.92 \\
\hline
\end{tabular}

Source: - 1) Annual Reports and Accounts, 2) Spot Studies; Results Computed.

Table IV:- Rank Correlation between Capital Structure and Earning Per Share

\begin{tabular}{|c|c|c|c|c|c|c|}
\hline Name of the Company & $\begin{array}{c}\text { Debt to } \\
\text { Equity }\end{array}$ & $\begin{array}{c}\text { Capital } \\
\text { Structure } \\
\text { Rank }\left(\mathrm{r}_{1}\right)\end{array}$ & $\begin{array}{c}\text { Earning } \\
\text { Per Share }\end{array}$ & $\begin{array}{c}\text { Earning } \\
\text { Per Share } \\
\text { Rank }\left(\mathrm{r}_{2}\right)\end{array}$ & $\begin{array}{c}\left(\mathrm{r}_{1}-\mathrm{r}_{2}\right) \\
\mathrm{d}\end{array}$ & $\mathrm{d}^{2}$ \\
\hline Bajaj Auto Ltd. & 0.01 & 6 & 108.90 & 2 & 4 & 16 \\
\hline Tata Motors Ltd. & 0.81 & 2 & -1.64 & 6 & -4 & 16 \\
\hline Hero Moto Corp. & 0.06 & 4 & 121.42 & 1 & 3 & 09 \\
\hline Maruti Suzuki India & 0.05 & 5 & 100.42 & 3 & 2 & 04 \\
\hline Ashok Layland & 0.84 & 1 & 1.52 & 5 & -4 & 16 \\
\hline TVS Motor Company & 0.47 & 3 & 5.92 & 4 & -1 & $\sum d^{2}=62$ \\
\hline
\end{tabular}

Source: - 1) Annual Reports and Accounts, 2) Spot Studies; Results Computed.

$\mathrm{R}^{1}=1-\frac{6-\left\{\sum d^{2}+\sum\left(t^{3}-t\right) / 12\right\}}{n^{3}-n} \quad$ Putting the values, we get $\mathrm{R}^{1}=-2.1$

Probable Error (P.E.), ' $r$ ' $=0.6745 \times \frac{1-r^{2}}{\sqrt{n}}$ Putting the values, we get ' $r$ ' $=-0.94$

Table V:- OLS Results with Time Dummies.

\begin{tabular}{|c|c|c|c|}
\hline Source & SS & df & MS \\
\hline Model & 68872.1742 & 5 & 13774.4348 \\
\hline Residual & 28391.4646 & 24 & 1182.97769 \\
\hline Total & 97263.6388 & 29 & 3353.91858 \\
\hline
\end{tabular}

Source: - 1) Annual Reports and Accounts, 2) Spot Studies; Results Computed.

No. of Obs $=30 ; \mathrm{F}(5,24)=11.64 ;$ Prob $>$ F = 0.0000; R-Squared = 0.7081;

Adj R-Squared = 0.6473; Root MSE = 34.394

\begin{tabular}{|c|c|c|c|c|}
\hline $\mathrm{Y}$ & Coefficient & Std. Error & $\mathrm{t}$ & $\mathrm{P}>|\mathrm{t}|$ \\
\hline $\mathrm{X}$ & -120.799 & 16.15424 & -7.48 & 0.000 \\
\hline $\mathrm{d} 12$ & -8.67715 & 19.99218 & -0.43 & 0.668 \\
\hline $\mathrm{d} 13$ & -5.477837 & 20.03217 & -0.27 & 0.787 \\
\hline $\mathrm{d} 14$ & -3.382158 & 20.00822 & -0.17 & 0.867 \\
\hline $\mathrm{d} 15$ & 3.045143 & 20.07332 & 0.15 & 0.881 \\
\hline -Cons & 104.0474 & 14.58859 & 7.13 & 0.000 \\
\hline
\end{tabular}

Source: - 1) Annual Reports and Accounts, 2) Spot Studies; Results Computed.

The time dummies are insignificant. But $\mathrm{X}$ has a significant influence on $\mathrm{Y}$. The constant is also significant. The coefficient of $\mathrm{X}$ is significant at $1 \%$ level. 
Table VI:- OLS Regression Results without Time Dummies.

\begin{tabular}{|c|c|c|c|}
\hline Source & SS & df & MS \\
\hline Model & 68368.5837 & 1 & 68368.5837 \\
\hline Residual & 28895.0551 & 28 & 1031.96625 \\
\hline Total & 97263.6388 & 29 & 3353.91858 \\
\hline
\end{tabular}

Source: - 1) Annual Reports and Accounts, 2) Spot Studies; Results Computed.

No. of Obs $=30 ; \mathrm{F}(1,28)=66.25 ;$ Prob $>\mathrm{F}=0.0000 ; \mathrm{R}-$ Squared $=0.7029$;

Adj R-Squared $=0.6923 ;$ Root MSE $=32.124$

\begin{tabular}{|l|l|l|l|l|l|l|}
\hline $\mathrm{Y}$ & Coefficient & Std. Error & $\mathrm{t}$ & $\mathrm{P}>|\mathrm{t}|$ & \multicolumn{2}{|l|}{ [95\% Conf. Interval] } \\
\hline $\mathrm{X}$ & -121.112 & 14.87962 & -8.14 & 0.000 & -151.5916 & -90.63253 \\
\hline Cons & 101.2658 & 8.074804 & 12.54 & 0.000 & 84.72531 & 117.8063 \\
\hline
\end{tabular}

Source: - 1) Annual Reports and Accounts, 2) Spot Studies; Results Computed.

$\mathrm{Y} \longrightarrow$ EPS (i.e. Earnings per Share)

$\mathrm{X} \rightarrow \mathrm{D} / \mathrm{E}$ (i.e. Debt-Equity)

$X$ increases $Y$ decreases and vice versa. At $1 \%, \mathrm{H}_{0}: \beta=0 ; \mathrm{H}_{1}: \beta \neq 0$

$\mathrm{X}$ is a significant determinant of $\mathrm{Y}$.

\section{Research Opportunities:-}

The study mainly based on secondary data is subject to all the limitations that are inherent in secondary data. Besides this, the study is employed on accounting based measures of profitability. Despite these limitations, further research may be carried on with the inclusion of more units within the automobile industry and using other market based measures of the capital structure and earnings per share. For drawing more meaningful conclusion in the context of this research problem, an in-depth study may be explored for different units for different industries over a longer period of time.

\section{Conclusion:-}

From the foregoing analysis, it has been observed that automobile companies capital structure is not much influential on earning per share which might be due to some other possible reasons. The present study has certain limitations, which provide scope for further research studies. The sample size selected is not large enough to make generalized conclusions. The result is confined to five years' data which again poses a question mark relating to the authenticity of results. A more research work can be done for predicting the capital structure and its impact on earnings per share.

The pattern of debt-equity structure being a continuous process changes from inception as compared to expanding the business. The decision is usually concerned with proportion of debt-equity mix to the extent the internal as well as external fund is used. Capital structure in India differs from company to company, industry to industry but it is expected a homogeneous pattern in similar type of industry. On the other hand, earning per share is expected to be dependent or co-related with capital structure. An appropriate capital structure generates highest earning per share.

Though the conclusion based on the above analysis has its own limitations, even then, it serves as a pointer to the prevailing practices, based on which many financial policy decisions can be taken.

\section{References:-}

1. Khan, M.Y. and Jain, P.K. (1992), "Financial Management Text and Problems", Edition 2nd, Tata McGraw Hill Publishing Company Ltd., New Delhi, p. 518.

2. Singh, S and Luthra, R (2013), "A Comparative Study of Trends in Corporate Capital Structure Pattern of Refinery and Metal Industry", Asia Pacific Journal of Marketing and Management Review, Vol. 2 (6), June, 2013.

3. Pratheepkanth, P (2011), "Capital Structure and Financial Performance: Evidence from selected Business Companies in Colombo Stock Exchange Srilanka", Researchers World Journal of Arts, Science and Commerce, Vol. 2, Issue-2, April, 2011.

4. Shubita, F.M. and Alsawalhah, M.J. (2012), "The Relationship Between Capital Structure and Profitability", 
International Journal of Business and Social Science, Vol. 3, No. 16, Special Issue, August, 2012.

5. Mohammadzadeh, M. Rahimi, Ararabi, F., M.S. and Salamzadeh, J. (2013), "The Effect of Capital Structure and Profitability of Pharmaceutical Companies - The Case Study of Iran", Iranian Journal of Pharmaceutical Research, July, 2013.

6. Poddar, N. and Mittal, M. (2014), "Capital Structure determinants of Steel Companies in India: A Panel Data Analysis”, Galaxy International Interdisciplinary Research Journal, Vol. 2 (1), January, 2014.

7. Modiglinani, F. and Miller, M.H. (1958), "The Cost of Capital, Corporation Finance and the Theory of Investment", American Economics Review, Vol. 48 (3), pp. 261-297.

8. Modiglinani, F. and Miller, M.H. (1963), "Corporate Income Taxes and the Cost of Capital: A Correlation", American Economics Review, Vol. 53 (3), pp. 433-443.

9. Myers, S.C. (1977), "Determinants of Corporate Borrowing”, Journal of Financial Economics, Vol. 113, No. 3, pp. 733-771.

10. Graham, J.R. (2000), "How Big Are the Tax Benefits of Debt?", The Journal of Finance. Vol. 55, No. 5, pp. 1901-1942.

11. Harris, M. and Raviv, A. (1991), "The Theory of Capital Structure”, Journal of Financial Economics, Vol. 41, No. 1, pp. 297-355.

12. Myers, S.C. (2001), "Capital Structure”, The Journal of Economic Perspectives, Vol. 15, No. 2 , pp. 81-102.

13. Asthana, B.N. (1976), "Elements of Statistics”, Chaitanya Publishing House, Allahabad, edn. VII, pp. $234-236$. 